\title{
Minha experiência com grupos em tempos de pandemia ${ }^{167}$
}

\section{Talita Rodrigues de Oliveira ${ }^{168}$}

A pandemia da COVID-19 nos colocou diante de uma crise global com repercussões em várias áreas: sanitária, econômica, política, social, e individual. À nível sanitário estamos diante de uma crise como não vemos há muitos anos e pude testemunhar diversas mudanças no Hospital das Clínicas, com o intuito de enfrentar a pandemia: novas contratações, aumento do número de leitos de UTI, protocolos de prevenção de infecção hospitalar e isolamento de um prédio inteiro somente para pacientes com COVID-19 foram alguns deles.

Nesse contexto de preparação, pude observar diversos movimentos das pessoas dentro das equipes de cada setor, e mais amplamente, como um grande grupo dentro da instituição. Frente à essas inúmeras mudanças implementadas pelo hospital, e diante de um panorama desolador, houve um aumento crescente do número de afastamento por causas psiquiátricas e pedidos de demissão no hospital.

Em “Experiências com Grupos”, Bion fala sobre como se dá a formação de um grupo e as dinâmicas que o compõe. Um inimigo comum é um dos fatores que favoreceriam a formação de um grupo, que então poderia estabelecer certas características, representantes de um inconsciente grupal, onde se manifestam angústias primitivas do indivíduo, a qual ele denomina de pressupostos básicos.

Nesse primeiro momento o pressuposto básico de luta e fuga se estabeleceu, e para quem ficou para lutar, o coronavírus se tornava o inimigo comum que aglutinava os profissionais do hospital a lutarem contra ele. De fato, um clima de guerra se instaurou, evocado pela luta, pelo risco de invasão e de morte. Não por acaso uma das campanhas de arrecadação de dinheiro para o HC teve justamente o slogan \#vempraguerra, e em outras campanhas realizadas pelo hospital, seus profissionais eram chamados de heróis, em uma tentativa de elevar o moral deles. A mídia, e sobretudo as redes sociais, reforçam o estereótipo dos heróis que tudo enfrentam e tudo suportam, sem se atentarem para a desumanização que o fazem ao impor esse título.

\footnotetext{
${ }^{167}$ Apresentado em Trabalhos livres no II Simpósio Bienal SBPSP "Fronteiras da Psicanálise: a clínica em movimento" no dia 28 de agosto de 2020.

${ }^{168}$ Membro filiado do Instituto Durval Marcondes da SBPSP. Médica assistente do Núcleo Técnico de Humanização do Hospital das Clínicas da USP.
} 
Diante desse cenário, foi grande a necessidade de apoio psicológico, e o Núcleo Técnico de Humanização, setor que eu trabalho, em parceria com a Divisão de Enfermagem, implementaram o programa "Enfermagem que Acolhe" para suas equipes. Criado em 2016, consiste em grupos terapêuticos voltados para equipes de enfermagem, necessidade que se antes já se mostrava necessária, agora é urgente.

Com milhares de enfermeiros trabalhando no Instituto Central, tivemos a oportunidade de oferecer esse cuidado com o apoio de voluntários residentes de psiquiatria e psicologia, tornando viável a possibilidade de oferecermos grupos presenciais em todos os turnos de trabalho, atendendo até 60 pessoas por semana. Um projeto ousado que não ocorreu sem dificuldades: as diversas perturbações ocorridas por conta do aumento da sobrecarga de trabalho, das inúmeras contratações e treinamentos, por vezes impediu a formação e continuidade dos grupos.

Inicialmente pensamos em manter o formato que era realizado antes da pandemia: grupos de 4 encontros com as mesmas pessoas. Depois, diante das dificuldades enfrentadas, tivemos que adaptar o formato para grupos abertos, rodas de conversa de um encontro único. Inicialmente tive dúvidas do quão terapeutico seria um grupo de encontro único, mas entendi que era a única possibilidade no contexto em que nos encontramos, e de fato, essa mudançan foi essencial para a viabilidade do programa. Assim, diante de uma situação impossível, oferecemos o que era possível.

O medo de contaminar os familiares é o tema mais recorrente nos grupos. A maioria desses profissionais rearranjaram suas rotinas diárias quando retornam do trabalho para casa: tiram a roupa que estão usando e lavam, desinfectam seus pertences com álcool, tomam banho em seguida, e cumprimentam seus familiares somente após todo esse ritual. Não é incomum, entre esses profissionais, a decisão de mandar os filhos pequenos para morar com os avós, ou de dormir separado do cônjuge, ou mesmo morar em outro lugar nesse período.

O medo de contaminar esconde também o seu oposto: o medo de se contaminar e de ser aniquilado. Parece difícil para eles admitirem o medo que sentem, sob julgo de serem profissionais despreparados ou de não corresponderem ao título de heróis insistentemente evocado. Esse medo aparece 
implícito por meio de relatos de colegas de profissão ou de casos de pacientes saudáveis e da mesma faixa etária que eles que foram internados na UTI ou que faleceram por COVID-19,

A comunidade e a família desses enfermeiros, por sua vez, tendem a vê-los como alguém contaminado, com potencial de transmitir a doença, o que gera situações de discriminação. São chamados de “COVID”, são evitados por vizinhos, isolados em quartos pela família, culpabilizados quando alguém do círculo deles se contamina. Houve quem tenha sido agredido verbalmente e fisicamente, além de expulso do transporte público no trajeto ao trabalho. Seja como herói, seja como escória, os dois títulos desumanizam esses profissionais e ambos levam à solidão.

O hospital, apesar do estresse e da sobrecarga, parece ser o lugar onde mais se sentem à vontade, e paradoxalmente, seguros. A utilização de equipamentos e o rigoroso protocolo de controle de infecção, dão a sensação de segurança e proteção, e para aqueles que não se contaminaram, mostra ser possível vencer o vírus. Ademais, parece ser um consenso entre eles que apesar de tudo, preferem o trabalho no hospital a ficar em casa em quarentena.

Surge então a potência, por vezes esquecida, por vezes exagerada me fazendo pensar em uma defesa maníaca. Essa potência é o que os reavivam, que os motivam a ir ao trabalho, que os ajudam a enfrentar esse momento. Alternadamente, surge muita impotência também, principalmente ao refletirem sobre o número de mortos que vêem todos os dias, da imprevisibilidade da doença, da impressão de darem tudo de sí ao paciente e ele morrer. Falam de uma sensação de trabalharem de modo distanciado dos pacientes e de si mesmos: "Vi duas pessoas (mortas) na maca na semana passada. Levei um susto. Duas pessoas mortas de uma vez. Fiquei triste. Parece que faço tudo no piloto automático, mas quando vi aquelas duas pessoas na maca... me dei conta disso tudo... fiquei triste".

Como trabalhar questões tão delicadas em um único encontro? Sinto o trabalho de forma muito dinâmica, rápida, e me esforço para não perder os fios daquela trama que é tecida à muitas mãos. Os grupos falam da propria experiência, opinam e indicam soluções entre si, aguentam as incertezas e a imprevisibilidade. Abre-se uma janela de oportunidade para se falar dos sentimentos, de conectar vivências com afetos que parecem adormecidos. 
Por outro lado, nem todos os grupos são assim, e por vezes eles buscam na minha figura a pessoa que irá dar respostas, que irá oferecer curas mágicas para seu sofrimento, ou seja, um grupo de pressuposto básico de dependência, como formulado por Bion. Quanto mais adoecido a composição do grupo, menos os indivíduos acreditam na força do outro e mais insistem em procurar em mim a oferta de algo que possa restituí-los. Resisto à "realização de uma psicoterapia individual em público", demandada de maneiras diversas e mais ou menos diretas, e insisto na construção das possibilidades com o grupo: quem mais pensa o mesmo? Quem pensa diferente? Alguém mais está vivendo isso? O que vocês estão sentindo agora? O tempo é curto, e só tenho aquele momento para tentar construir algo, e sigo ativa nessa construção junto a eles.

Depois de tanto tempo sob a opressão desse inimigo invisível, sob uma atmosfera de opressão e de luta, há algumas semanas me chamou a atenção um novo movimento que parece ser o do pressuposto básico de acasalamento. Nesse pressuposto, Bion chama a atenção para grupos que parecem viver um porvir onde surgirá um líder, uma idéia ou qualquer coisa que irá salvar o grupo. Nesse momento, não só os grupos, mas também meus colegas de trabalho, amigos, familiares falam com uma certa insistência dessa salvadora tão desejada: a vacina. Quando virá a vacina para nos salvar desse horror?

Interposta à esse futuro mítico, onde terá fim todo o sofrimento, fica outra pergunta: até quando a pandemia irá durar? A experiência do tempo fica suspensa diante das inúmeras demandas que surgem no hospital e fora dele, de modo que não ter uma data de término traz a sensação de que esse momento durará para sempre, e com ele, o sofrimento, o cansaço, a angústia. É frequente a afirmação: "Se a gente soubesse quando isso vai terminar, seria mais fácil encontrar forças”.

Os grupos se mostram um espaço não só para desabafar as angústias e as vivências dolorosas, mas também um espaço de apoio mútuo, de reflexão, de tolerância com o desconhecido e a possibilidade de conexão consigo mesmo e os colegas. Se no início tinha dúvidas sobre o benefício de um único encontro, essa experiência me mostrou que a psicanálise é um campo fértil quando conseguimos ser flexíveis com o setting e se formos capazes de adaptarmos a técnica psicanalítica de acordo com as necessidades. 
Ainda sem expectativas de quanto tempo a pandemia irá durar, com a curva de contaminados ainda em crescimento e o Hospital das Clínicas sendo referência em casos de COVID-19, seguiremos com os grupos enquanto for possível e necessário. $\mathrm{O}$ meu relato portanto termina aqui, mas a jornada ainda não.

\section{Referências}

Bion, W. R. (1970). Experiências com Grupos (W. I. de Oliveira, Trad., $1^{\text {a }}$ ed.). Rio de Janeiro: Imago. (Trabalho original publicado em 1961. Título original: Experiences in Groups and Other Papers). 